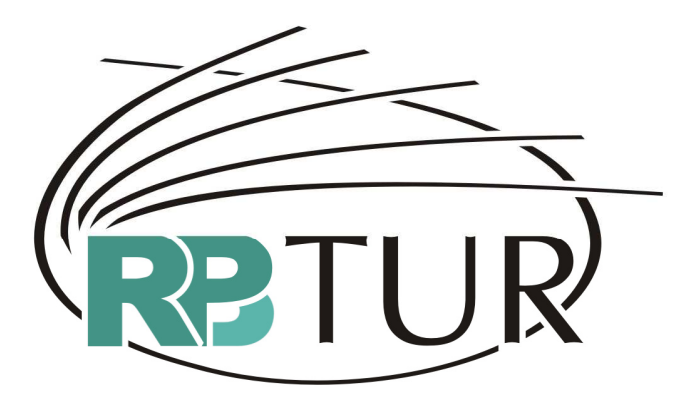

REVISTA BRASILEIRA DE PESQUISA EM TURISMO

\title{
EDITORS' PAGE
}

The spanish poet Antonio Machado wrote "caminante, no hay camino, se hace el camino al andar". (walker, there is no trail, trail is made through walking). And that's what we are doing, walking our trail to Brazilian tourismology and, as a part of it, we proudly present the first issue of Revista Brasileira de Pesquisa em Turismo (Brazilian Tourism Research Journal), sponsored by ANPTUR- Associação Nacional de Pesquisa e Pós Graduação em Turismo. National Association for Research and Post Graduate Studies in Tourism.

The intention of this journal is to contribute as strongly as possible with the scientifization of tourism studies carried out in Brazil and around the world, with articles issued from plural researches made by multiple disciplines expecting one day tourism, as a total phenomenum, be the object of transdisciplinar studies.

Many statemens have been made about tourism impacts in society, but there are not many researches which can prove them. Economists have for sure that tourism generates many jobs and has a great multiplyier effect. Nevertheless, which kind os jobs tourism generates needs to be studied, as well as the real amount of the multiplyer effect, or which is the role of income tax evasion in tourism economy and which the relation this last issue has with social history. There are also few researches on tourism impacts on traditional ways of production. 
From a sociological and anthropological point of view, it is necessary to broaden researches on the effect womens'jobs in the industry have had in traditional families, thus linking tourism with gender and identity issues. It is also important to study the influence ethnicity and nationality have in tourism employment, as well as the relation between migration and tourism and the rising transformation of migrants into tourists and vice versa.

Several studies have been made in the last thirty years years on acculturation processes suppossedly triggered by tourism. It is necessary, nevertheless, to verify how acculturation and social history and self esteem of people are related.

About 1980 advocates of the so called adaptancy platform proposed new forms of tourism which could favor hosts and gests contacts. But it is still necessary to evaluate the influence of prejudice and stereotyping in this contacts and where the limit stays before convival turns into provacy invasion. It is also necessary to watch over health issues in tourism, for example in rural tourism where guests are usualy lodged into the family house. And, above all, it is important to watch over the aceitable limit of tourismification of spaces and habits.

The editors know that the answer to these questions is not easy, because disembedding tourism from other social phenomena which can have causal relation with it or not is a very difficult task.

But in spite of hardships tourism research can have we know we are doing the right thing, opening our path, with a scientific community which is working hard to make serious researches on this fascinanting, complex and diversified object. 
The e-journal format and the free access will allow that every person can reach to the articles, anywhere, so permitting a broad diffusion of knowledge, without phisical or economical barriers, as it is the mission of ANPTUR as a scientific organization.

This first number brings articles on education, teaching, souvenirs, collective memory and museums.

Ari da Silva Fonseca Filho studies education for tourism in first grade schools and concludes that programmes have as a result good tourists and good hosts.

Bianca Freire-Medeiros and Celso Castro analysis on souvenirs shows how theses pieces are a part of Rio de Janeiro's touristic image, and that many times something that for "cariocas" is kitsch, appears is nice for tourists who buy it with enthusiasm.

Ceres Karam Brum analyzes how colective memory is constructed in the region known as Missões, where some projects on religious tourism are being held. As a conclusion she states that a dialectic relation exists between the official tourist plan and the local perspectiva but, nevertheless, the tourism experience is $\mathbf{X X X X X X X X X x e d i f i c a n t e . ~}$

Márcia M. Cappellano dos Santos argues that as a paradox, more scientific studies on tourism have not turned into new pedagogical forms. To make some advances in this field, she presents a sucessfull experience with professors in tourism education.

From a neighbour country Tânia Siedlecki Huerta sends her contribution describing changes held in museums to face tourism demand, incorporating new commucation techniques and the concepts of dialogism, otherness and multiculturality. 
This volume brings also a review of a polemic book writen by Helton Ouriques, and the chronique of the III International Symposium on Tourism Research held in Misiones, Argentina. 